\title{
A RATIONAL SYNTHESIS OF MAGNETIC NANOPARTICLES INCORPORATED HORSERADISH PEROXIDASE NANOFLOWER AND ITS USE FOR THE REMOVAL OF PHENOL THROUGH OXIDATIVE COUPLING REACTION WITH GREAT REUSABILITY
}

\author{
Cevahir ALTINKAYNAK, Department of Plant and Animal Production, Avanos Vocational School, Nevsehir Haci Bektas Veli \\ University, 50500, Nevsehir, Turkey, caltinkaynak@nevsehir.edu.tr \\ (iD) https://orcid.org/0000-0003-0082-8521) \\ Nalan ÖZDEMIR*, Department of Chemistry, Faculty of Science, Erciyes University, Kayseri, 38039, Turkey, \\ ozdemirn@erciyes.edu.tr \\ (iD) https://orcid.org/0000-0002-8930-5198)
}

İsmail ÖÇSOY, Department of Analytical Chemistry, Faculty of Pharmacy, Erciyes University, Kayseri, 38039, Turkey, ismailocsoy@erciyes.edu.tr

(D) https://orcid.org/0000-0002-5991-3934)

Received: 14.08.2021, Accepted: 07.12.2021

*Corresponding author DOI:10.22531/muglajsci.982993

\begin{abstract}
Herein, we report preparation of magnetic hybrid nanoflower (MhNF) formed of horseradish peroxidase (HRP), copper ions $\left(\mathrm{Cu}^{2+}\right)$ and iron oxide nanoparticles $\left(\mathrm{Fe}_{3} \mathrm{O}_{4} \mathrm{NPS}\right)$ with greatly enhanced activity, stability, reusability and applicability for use in removal of phenol from aqueous solution. In this study, pre-synthesized small sized $\mathrm{Fe}_{3} \mathrm{O}_{4} \mathrm{NPs}_{\text {were immobilized to }}$ synthesized HRP-Cu ${ }^{2+}$ hybrid nanoflower ( $h N F$ s). The synthesized MhNFs were characterized using SEM, EDX and XRD analysis. We also characterized the chemical structures of free HRP and MhNF using FTIR. The protein encapsulation yields of synthesized MhNFs were determined spectrophotometrically and calculated as $\sim 98 \%$ for all synthesis conditions. The activities of free HRP, HRP-based non-magnetic hybrid nanoflower (hNF) and MhNF were calculated as 5847.6, 16738.2, and $18830.5 \mathrm{EU} / \mathrm{mg}$, respectively. The optimum $\mathrm{pH}$ of the synthesized MhNFs for phenol removal was determined as $\mathrm{pH} 7$. $M h N F$ was easily and rapidly separated from reaction medium by an external magnetic field to be re-used. Even after seven cycles, MhNFs maintained more than 75\% of their initial activity. We believe that the repeated use can reduce the capital and operation costs. The results are very promising in terms of increasing efficiency and applicability of HRP in industrial application especially for wastewater treatment.
\end{abstract}

Keywords: Enzyme-inorganic hybrid nanoflower, enzyme activity, magnetic hybrid nanoflower, peroxidase, phenol removal

\section{MANYETIKK NANOPARTİKÜLLE BİRLEŞTİRILLIŞ YABAN TURPU PEROKSİDAZ ENZIMİ İÇEREN TEKRAR KULLANILABİLIR ÖZELLİKLİ NANO ÇİÇEKLER İÇİN RASYONEL BİR SENTEZ VE OKSIDATIFF KUPLAJ REAKSIYONUYLA FENOL GIDERIMINDE KULLANIMLARI}

\section{Özet}

Bu çalışmada, mükemmel şekilde güçlenmiş aktivite, stabilite, tekrarkullanılabilirlik ve sulu çözeltilerden fenol gideriminde kullanılacak yaban turpu peroksidaz (HRP), bakır iyonları $\left(\mathrm{Cu}^{2+}\right)$ ve demir oksit nanoparçacıklarından $\left(\mathrm{Fe}_{3} \mathrm{O}_{4} \mathrm{NP}^{\prime} \mathrm{ler}\right)$ oluşan manyetik hibrit nano çiçeklerin (MhNF) hazırlanması rapor edildi. Önceden sentezlenmiş küçük boyutlu $\mathrm{Fe}_{3} \mathrm{O}_{4}$ $N P^{\prime} l a r$, sentezlenen HRP-Cu ${ }^{2+}$ hibrit nano çiçeklere ( $\left.h N F^{\prime} l e r\right)$ immobilize edilmiştir. Sentezlenen MhNF'ler SEM, EDX ve XRD analizi kullanılarak karakterize edildi. Ayrıca FTIR kullanılarak serbest HRP ve MhNF'nin kimyasal yapıları da karakterize edildi. Sentezlenen MhNF'lerin protein kapsülleme verimleri spektrofotometrik olarak belirlendi ve tüm sentez koşulları için \%98 olarak hesapland. Serbest HRP, HRP bazlı manyetik olmayan hibrit nano çiçek (hNF) ve MhNF'nin aktiviteleri sirasıla 5847.6, 16738.2 ve $18830.5 \mathrm{EU} / \mathrm{mg}$ olarak hesaplanmıştır. Sentezlenen MhNF'lerin fenol giderimi için optimum pH'ı 7 olarak belirlendi. MhNF, tekrar kullanılmak üzere harici bir manyetik alan oluşturularak reaksiyon ortamından 
kolaylıkla ve hızla ayrıldı. Yedi döngüden sonra bile, MhNF'ler başlangıç aktivitelerinin yaklașık \%75'inden fazlasını korudu. Tekrarlanan kullanımın sermaye ve işletme maliyetlerini azaltabileceğine inanıyoruz. Sonuçlar, özellikle atık su arıtımı için endüstriyel uygulamada HRP'nin verimliliğinin ve uygulanabilirliğinin arttırlması açısından çok umut vericidir.

Anahtar Kelimeler: Enzim-inorganik hibrit nanoçiçek, enzim aktivite, manyetik hibrit nanoçiçek, peroksidaz, fenol giderimi Cite

Altınkaynak, C., Özdemir, N., Öçsoy, İ., (2021). “A Rational Synthesis of Magnetic Nanoparticles Incorporated Horseradish Peroxidase Nanoflower and Its Use for The Removal of Phenol Through Oxidative Coupling Reaction with Great Reusability", Mugla Journal of Science and Technology, 7(2), 59-66.

\section{Introduction}

Peroxidases (EC:1.11.1.x) are a member of the oxidoreductase family and they catalyze the oxidation reactions of various organic and inorganic substrates including phenols. And there is an enhanced curiosity in the extraction and purification of peroxidase enzymes for their economically use in biomedical, biotechnological and industrial applications [1,2,3]. Among these enzymes, horseradish peroxidase (HRP) is the most widely studied peroxidase. HRP is an important molecule for several applications including biomedical, biotechnological, clinical, industrial and environmental, because of its wide substrate specificity, broader catalytic activity, and high sensitivity [4]. It can be also operated at wide ranges of $\mathrm{pH}$ and temperature and its activity can be spectrophotometrically measured [3]. Unfortunately, water-soluble (free) enzymes have some disadvantages, such as short life time in solution, inconvenient recovery, lack of long-term operational stability and reusability, which strictly hinder their aforementioned applications $[5,6,7]$. To overcome these issues, many novel methods like enzyme immobilization, enzyme modification, and protein engineering etc. are being used [8]. Especially several immobilization techniques have been developed by associating enzymes to various support materials $[9,10,11]$. Although immobilized enzymes can be easily separated from the reaction media for reusability, improved stability towards environmental changes, and can used for bioreactor designs $[5,12]$, most of them exhibited low catalytic activity compared to free enzymes $[12,13]$. The potential reasons for the decrease in catalytic activity of immobilized enzyme are related about the mass transfer limitations between enzyme and substrate, and unfavorable conformational changes in enzyme [14]. It is worthy to mention that enzyme immobilization approaches are very important issue in order to efficiently use enzyme for diverse implementations. In 2012, Zare and co-workers reported an epochal approach in immobilization by constructing flowerlike hybrid nanostructure formed of protein and copper ions $\left(\mathrm{Cu}^{2+}\right)$ with enhanced catalytic activity and stability [15]. Inspiring from this work, several researchers have synthesized and reported different kinds of organic inorganic hybrid nanoflowers and used them for a variety of applications [16-29].
Phenol mentioned as an one major toxic compounds by several countries including the Environmental Protection Agency have highly adverse effect to the living organisms [30]. Phenolic compounds are widely distributed as major environmental pollutants in industrial wastewaters [31,32] and can cause several human health problems, such as cancer, nervous and respiratory system problems, abnormal function of thyroid etc. [32]. Therefore, industrial wastewaters containing phenols need to be depurate before discharge into the environment. There is no one an internationally recognized wastewater treatment process. The method used is changed based on the type of waste water and pollution and so, many different biological methods, chemical and physical have been used. However, it is believed that the biological wastewater treatment is method of least damaging to the environment. Especially, oxidoreductase enzymes have been attractively used for the removal of phenolic compounds from wastewaters $[4,33,34,35,36,37]$. Several studies reported to increase interest for using the HRP to remove the phenolic compounds from aqueous media $[4,13,37]$. Therefore, the HRP-based catalytic systems have potential applications in phenolic pollutants including wastewater treatment.

Until now, various type of magnetic/organic-inorganic hybrid nanoflowers have been synthesized [19,22,38]. For instance, Cheon et al 2019 have synthesized glucose oxidase (GOx)-copper hybrid nanoflowers with $\mathrm{Fe}_{3} \mathrm{O}_{4}$ magnetic nanoparticles (MNPs-GOx NFs). When they synthesized the MNPs-GOx NFs, they first preparated amine-functionalized MNPs, then they combined MNPs and GOx, and finally bonded the final product MNPs-GOx NFs in metal ion and phosphate buffered medium [18]. The obtained MNPs-GOx NFs' demostrated increased peroxidase-like activity as substrate for using glucose determination. Lee et al 2020 also found that the MNPsGOx NFs showed a broad spectrum anti-bacterial activity against both $S$. aureus (Gram-positive) and E. coli (Gramnegative) [24]. Feng et. al 2020 reported a simple method to synthesize magnetic nanoflowers with papain as organic component [19]. In this study, the activated $\mathrm{Fe}_{3} \mathrm{O}_{4}$ nanoparticles surfaces adsorbed papain enzyme, then the papain- $\mathrm{Cu}_{3}\left(\mathrm{PO}_{4}\right)_{2} .3 \mathrm{H}_{2} \mathrm{O}$-magnetic nanoflowers were obtained using copper ion and magnetic nanoparticles with papain as in the previous study we mentioned. The obtained magnetic material exhibited $1556 \%$ increased activity than the free papain enzyme. 
Wang et al. 2018 reported that one-pot synthesis method of hemin-incorporated hybrid nanoflowers $(\mathrm{HCH})$ is produced using Con A and Hemin in PBS solution containing copper ions [26]. It was also found to be a compatible working component with antibody-labeled magnetic nanoparticle for colorimetric detection of foodborne pathogenic bacteria. In another study [29], the $\mathrm{Zn}_{3}\left(\mathrm{PO}_{4}\right)_{2}$ crystal and $\mathrm{BSA}$ were combined in a phosphate buffered medium to obtain $\mathrm{BSA} / \mathrm{Zn}_{3}\left(\mathrm{PO}_{4}\right)_{2} / \mathrm{Fe}_{3} \mathrm{O}_{4}$ magnetic hybrid particles, and used for the absorption of $\mathrm{Cu}$ (II). Guo et al 2019 reported that ferrous phosphate hybrid nanoflowers with GOx exhibited more stability, catalytic activity, and reusability compared with free enzymes [20]. Han et al 2019 expressed the preparation method of $\mathrm{Fe}_{3} \mathrm{O}_{4} @$ @MMG-IDA-Cu${ }^{2+}$ flower-like material via distillation-precipitation polymerization of glycidyl methacrylate (GMA) [22]. In the synthesis, $\mathrm{Fe}_{3} \mathrm{O}_{4} @$ @MGIDA was obtained, and then copper was absorbed onto its surface. Finally, the magnetic nanoflowers were synthesized using $\mathrm{Fe}_{3} \mathrm{O}_{4} @$ PMG-IDA-Cu${ }^{2+}, \mathrm{HRP}$ and PBS solution. They also investigated $\mathrm{pH}$ and thermal stability, and catalytic activity for degradation of BPA comparison with free HRP.

In this study, we report that the magnetic $\mathrm{Fe}_{3} \mathrm{O}_{4}$ particles and $\mathrm{HRP}-\mathrm{Cu}^{2+}$ hybrid nanoflower are synthesized separately, and then combined to obtain magnetic properties. The magnetic hybrid nanoflowers (MhNF) with greatly increased activity, stability, reusability and applicability for use in removal of phenol are formed of horseradish peroxidase (HRP) enzyme, copper ions $\left(\mathrm{Cu}^{2+}\right)$ and iron oxide nanoparticles $\left(\mathrm{Fe}_{3} \mathrm{O}_{4} \mathrm{NPs}\right)$. The synthesis of MhNF was completed with two following steps. In the first step, HRP-Cu${ }^{2+}$ hybrid nanoflower (hNF) was formed via coordination reaction between amine groups of HRP and copper ions. In the second step, pre-synthesized small sized $\mathrm{Fe}_{3} \mathrm{O}_{4}$ NPs (around $10 \mathrm{~nm}$ ) were treated $\% 5$ glutaraldehyde (GA) treated and immobilized o nanoflower (hNFs). MhNF was separated from reaction medium by an external magnetic field (magnet) to be easily re-used due to its magnetic feature. We believe that the repeated use can reduce the capital and operation costs. The results are very promising in terms of increasing efficiency and applicability of HRP in industrial application especially for wastewater treatment.

\section{Experimantal}

\subsection{Chemicals and materials}

Horse radish (HRP; EC 1.11.1.7), hydrogen peroxide $\left(\mathrm{H}_{2} \mathrm{O}_{2}\right)$, copper (II) sulfate pentahydrate, guaiacol, methanol, bovine serum albumin (BSA), phosphoric acid, coomassie brilliant blue G-250, 1,6-diaminohexane, sodium acetate, iron (III) chloride hexahydrate, ethylene glycol, ethyl alcohol, ammonium acetate, $\mathrm{CaCl}_{2}, \mathrm{MnCl}_{2}$, glutaraldehyde solution, $\mathrm{NaCl}, \mathrm{KCl}, \mathrm{Na}_{2} \mathrm{HPO}_{4}, \mathrm{KH}_{2} \mathrm{PO}_{4}$, $\mathrm{HCl}, \mathrm{NaOH}, 4$-aminoantipyrine (4-AAP), $\mathrm{K}_{3} \mathrm{Fe}(\mathrm{CN})_{6}$ and phenol were purchased from Sigma-Aldrich. All the following chemicals were of analytical grade.

\subsection{Preparation of magnetic hybrid nanoflower (MhNF)}

$1.8 \mathrm{~g}$ of 1,6-diaminohexane, $2 \mathrm{~g}$ of sodium acetate and $1 \mathrm{~g}$ of iron (III) chloride hexahydrate were dissolved into $15 \mathrm{~mL}$ of ethylene glycol, stirred until a transparent view. Then the mixture was transferred into a Teflon-line autoclave and incubated at $200^{\circ} \mathrm{C}$ for $6 \mathrm{~h}$. The autoclave was cooled to room temperature. The obtained amine capped $\mathrm{Fe}_{3} \mathrm{O}_{4}$ nanoparticles (NPs) were washed with ethyl alcohol 3 times, and then also washed with distilled water 3 times. The precipitates were dried in oven at $50^{\circ} \mathrm{C}$. Preparation of $\mathrm{Fe}_{3} \mathrm{O}_{4}$ NPs, synthesis of $\mathrm{HRP}_{-} \mathrm{Cu}^{2+}$ hybrid nanoflower and formation of magnetic featured $\mathrm{HRP}-\mathrm{Cu}^{2+}$ hybrid nanoflower (MhNF) were presented in Fig. 1, respectively.

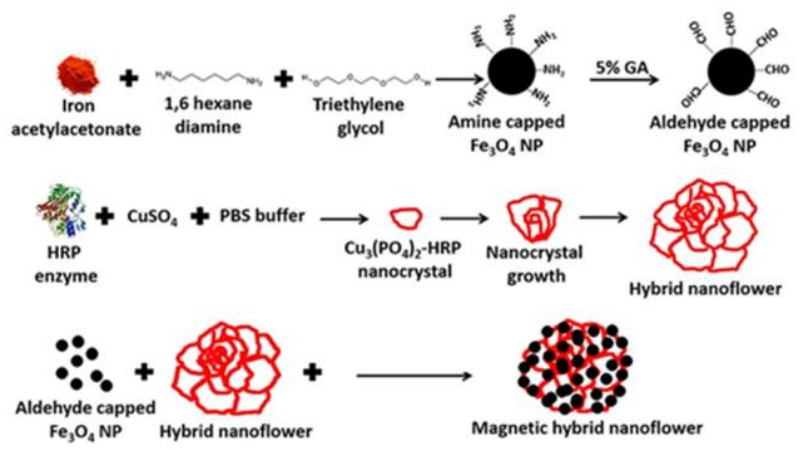

Figure 1. Preparation of MhNF

The hybrid nanoflowers were obtained following modified reported methods [15,27]. In a typical synthesis, the certain volume from $120 \mathrm{mM}$ aqueous $\mathrm{CuSO}_{4}$ freshly prepared as a stock solution was added to certain volume of PBS buffer ( $\mathrm{pH}$ 7.4) containing HRP enzyme $\left(0,02 \mathrm{mg} \mathrm{mL}^{-1}\right)$. The last concentration of $\mathrm{Cu}^{2+}$ is fixed to $0.8 \mathrm{mM}$. The resultant mixture was vortexed for $30 \mathrm{~s}$ prior to leave undisturbed for incubation at $+4^{\circ} \mathrm{C}$ for 3 days. After incubation, the precipitate as a product and indication of nanoflowers occurred at the bottom of the solution was collected by centrifugation at $10000 \mathrm{rpm}$ for $15 \mathrm{~min}$. The last product was re-dispersed and washed with distilled water 3 times to remove unreacted components and finally was dried under vacuum room at temperature $\left(\mathrm{RT}=25^{\circ} \mathrm{C}\right)$. Bradford protein method was used in determination of the enzyme concentration in the supernatant to calculate encapsulation yield. Fig. 1B shows the general scheme of hNFs formation.

$10 \mathrm{mg}$ of the amine capped $\mathrm{Fe}_{3} \mathrm{O}_{4} \mathrm{NPs}$ was dispersed in coupled buffer (CB) pH 8.3 (50 mM ammonium acetate, 1 $\mathrm{mM} \mathrm{CaCl} 2$ and $1 \mathrm{mM} \mathrm{MnCl}_{2}$ ) before treated with glutaraldehyde. $200 \mu \mathrm{L}$ of glutaraldehyde $5 \%$ in $\mathrm{CB}$ buffer-pH 7.0 was added to amine capped $\mathrm{Fe}_{3} \mathrm{O}_{4}$ nanoparticles $(10 \mathrm{mg})$, and incubated under vigorous stirring for $1.5 \mathrm{~h}$. After the incubation time, the precipitates were separated by a permanent magnet, then PBS buffer ( $1 \mathrm{~mL}, \mathrm{pH} 7.4$ ) was added into aldehyde capped $\mathrm{Fe}_{3} \mathrm{O}_{4} \mathrm{NPs}$ around $(10 \mathrm{mg})$. Finally, the activated $\mathrm{Fe}_{3} \mathrm{O}_{4}$ NPs were stored at RT as stock solution. For 
magnetic hybrid nanoflowers, $1 \mathrm{mg} / \mathrm{mL} \mathrm{hNF}$ and $40 \mu \mathrm{L}$ of activated magnetic $\mathrm{Fe}_{3} \mathrm{O}_{4} \mathrm{NP}$ (stock solution) were mixed into $800 \mu \mathrm{L}$ of PBS(pH 7.4). The mixture was stirred for $1.5 \mathrm{~h}$. After the incubation, the precipitates were separated by a permanent magnet, and then dried under vacuum at RT. The obtained HRP based magnetic hNF were stored for further use. Schematic representation of the preparation of HRP based MhNF is shown in Fig. 1C.

\subsection{Instrumentation and characterization}

The images of hNFs and magnetic hybrid nanoflower (MhNF) were generated using scanning electron microscopy (SEM, ZEISS EVO LS10). For that, dry hNF and MhNF powders were deposited on adhesive carbon tape covered stub before sputter coating device was used to coat the stub with gold for conductivity. Finally, SEM images were obtained. The elemental composition of each products were analyzed by energy-dispersive X-ray (EDX) analysis. The XRD measurements were performed on a BRUKER AXS D8 ADVANCE Model. FTIR spectra were collected with Perkin Elmer 400 spectrometer. The optical properties of samples were measured at room temperature with a UV-vis spectrophotometry (CheBios optimum-one).

\subsection{Enzymatic activity measurements}

The similar concentrations of free HRP, hNFs and MhNFs were used to determine their activities via colorimetric and spectroscopic methods against guaiacol as a substrate in PBS buffer (pH 6.8, $25^{\circ} \mathrm{C}$ ) $[1,3,27]$. First, free HRP, hNFs and MhNFs were separately dissolved in PBS buffer $\left(1 \mathrm{~mL}, \mathrm{pH} 6.8,25^{\circ} \mathrm{C}\right)$, and then hydrogen peroxide $\left(\mathrm{H}_{2} \mathrm{O}_{2}, 1 \mathrm{~mL}, 22.5 \mathrm{mM}\right)$ and guaiacol $(1 \mathrm{~mL}, 45 \mathrm{mM})$ were added in to each reaction tube. The last concentrations of guaiacol and $\mathrm{H}_{2} \mathrm{O}_{2}$ in the tubes were arranged as 15 and $7.5 \mathrm{mM}$, respectively. The changes in absorbance of oxidized guaiacol were recorded at $470 \mathrm{~nm}$ at $25^{\circ} \mathrm{C}$ using $\mathrm{UV}-\mathrm{Vis}$ spectrophotometry. One activity unit (EU) of HRP was defined as the amount of HRP required to catalyze 1 $\mu$ mol of substrate per mininute under the specified reaction

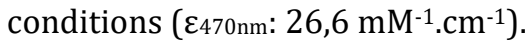

\subsection{Removal of phenol using magnetic hybrid nanoflower (MhNF)}

The concentration of total phenols was measured by using a colorimetric method. Phenolic materials react with 4-aminoantipyrine in the presence of potassium ferricyanide. Phenol has been selected as a standard for preparing standard curve by plotting instrument response concentration values. For calibration curve, a series of at least five standard phenol solution has been prepared (1 mL Phenol solution [x] in PBS-pH 7.0, $1 \mathrm{~mL}$ 4-AAP, $2 \mathrm{mM}$ and $\left.1 \mathrm{~mL} \mathrm{~K}_{3} \mathrm{Fe}(\mathrm{CN})_{6}\right), 6 \mathrm{mM}$. The obtained absorbance value will represent the concentration of phenolic compounds present in the sample.

For phenol removal assay, the identical amount free HRP and MhNFs were separately dissolved in PBS (pH 7.0) at room temperature. The initial concentration of phenol solution was $0.6 \mathrm{mM}$. Then $2.5 \mathrm{mM}$ hydrogen peroxide $\left(\mathrm{H}_{2} \mathrm{O}_{2}\right)$ was added to each reaction tube. When incubation period is completed for mentioned experiment, the pellet was easily collected to the bottom of the tube under favor of the magnet. The supernatant was also analyzed for detecting of residual phenol concentration as aforementioned. The absorbance values at $510 \mathrm{~nm}$ were transformed to phenol concentration in the samples after MhNFs treatment, using a calibration curve.

\section{Results and Discussion}

The synthesized MhNFs were characterized using SEM, EDX and XRD analysis. The elemental composition of the MhNF powders and peak positions of $\mathrm{Cu}_{3}\left(\mathrm{PO}_{4}\right)_{2}$ in the MhNFs were analyzed by EDX and XRD, respectively. The encapsulation yields of synthesized MhNFs were determined spectrophotometrically at $595 \mathrm{~nm}$ using the Bradford's method.

\subsection{Preparation and characterization of magnetic hybrid nanoflower (MhNF)}

The proposed mechanism of magnetic hybrid nanoflower (MhNF) formation is illustrated in graphical abstract. Standard synthesis protocol of proteininorganic hybrid nanoflower was also described before $[23,27]$. In a standard protocol, to obtain flower-like hybrid nanomaterials, a certain amount of $\mathrm{Cu}^{2+}$ is added to PBS solution containing certain amount of protein. In the mixture, firstly, the $\mathrm{Cu}^{2+}$ ions formed primary copper phosphate complexes with phosphate groups in phosphate buffer solution, then the protein attached to copper phosphate complexes through amine groups in the backbone of protein and $\mathrm{Cu}^{2+}$ ions to assemble hNF. The formation of hNF is hierarchically and kinetically started with n 6 hours and slowly completed within 3 days. Unlike other studies, in the present study after preparation of hNFs, magnetic featured was gained.

The presence of $\mathrm{Cu}$ and Fe metals in MhNFs was analyzed with EDX technique (Fig. 2A). The corresponding peaks of $\mathrm{Cu}$ and Fe clearly appeared on EDX spectrum. XRD spectrum showed the peak positions and relative intensities of the HRP enzymes in MhNF were characterized with XRD analysis (Fig. 2B). The diffraction peaks of $\mathrm{Cu}_{3}\left(\mathrm{PO}_{4}\right)_{2}$ nanocrystals in the MhNFs were almost well consistent with the JCPDS card (00-0220548).

We also characterized the chemical structures of free HRP and MhNF using Fourier Transform Infrared Spectroscopy (FTIR) (PerkinElmer Spectrum 400). Both free HRP and MhNF powders were dried at $70^{\circ} \mathrm{C}$. And then, they were mixed with IR-grade $\mathrm{KBr}$ and pressed into tablet form. The characteristic peaks of HRP and MhNF were presented on the FTIR spectrum (Fig. 3A and 3B). O P O groups showed the bending vibrations at $\sim 562$ $\mathrm{cm}^{-1}$ and $\sim 556 \mathrm{~cm}^{-1}$ for free HRP and MhNF, respectively. 

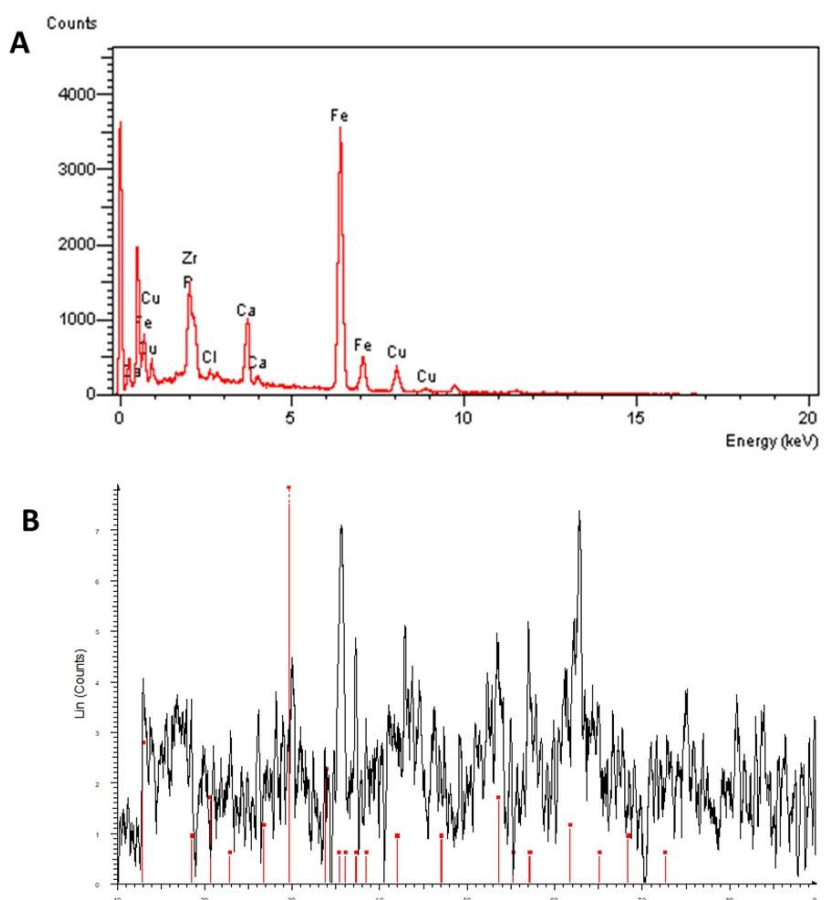

Figure. 2. (A) EDX analysis of the synthesized MhNFs, (B) XRD patterns of the synthesized MhNFs.

The very intense bending vibration of $\mathrm{O} P \mathrm{P}$ groups was revealed in the MhNF due to packed of HRP in MhNF. Additionally, MhNF presented very strong P O stretching bands at $\sim 1042 \mathrm{~cm}^{-1}$ and $\sim 1147 \mathrm{~cm}^{-1}$ while very weak stretching bands appeared for free HRP. The vibration bands of $-\mathrm{NH}_{2}$ groups at $\sim 1634 \mathrm{~cm}^{-1}$ and $\sim 1621 \mathrm{~cm}^{-1}$ were for free HRP and MhNF, respectively. Finally, its stretching bands of it at 3000-3300 were attributed to $\mathrm{CH}_{2}$ and $-\mathrm{CH}_{3}$ groups of free HRP and MhNF.

TEM image of the $\mathrm{Fe}_{3} \mathrm{O}_{4}$ NPs is clearly shown in Fig. 4A. The shape of $\mathrm{Fe}_{3} \mathrm{O}_{4}$ NPs is in spheres and their sizes are in the size range of $10-20 \mathrm{~nm}$. The hNFs are quite uniform and monodisperse. They have spherical shapes with diameters of $\sim 5 \mu \mathrm{m}$ size (Fig. 4B). The grain boundaries of HRP leaves in hNFs are observed in the highmagnification image of Fig. 4C. It is also evidence than how HRP petals act as a 'glue' to bind the petals together for for nanoflower self-assembly. The post modification of pre-synthesized $\mathrm{Fe}_{3} \mathrm{O}_{4} \mathrm{NPs}$ to hNFs for formation of MhNFs was achieved (Fig. 4D).

The high-magnification image of Fig. 4E shows the binding and insertion of $\mathrm{Fe}_{3} \mathrm{O}_{4} \mathrm{NPs}$ to hNFs. The blue color of hNFs solution was turned into black color after binding of $\mathrm{Fe}_{3} \mathrm{O}_{4} \mathrm{NPs}$ to hNFs as shown in Fig. $4 \mathrm{~F}$ (left). We also claim that MhNFs is quite water-soluble and stable in aqueous solution compared to hNFs. To test the magnetic property of MhNFs, we used a magnet (the external magnetic field). When a magnet was touched to a glass vial, the MhNFs were rapidly collected on the glass wall where a magnet placed as shown in Fig. 4F (right).

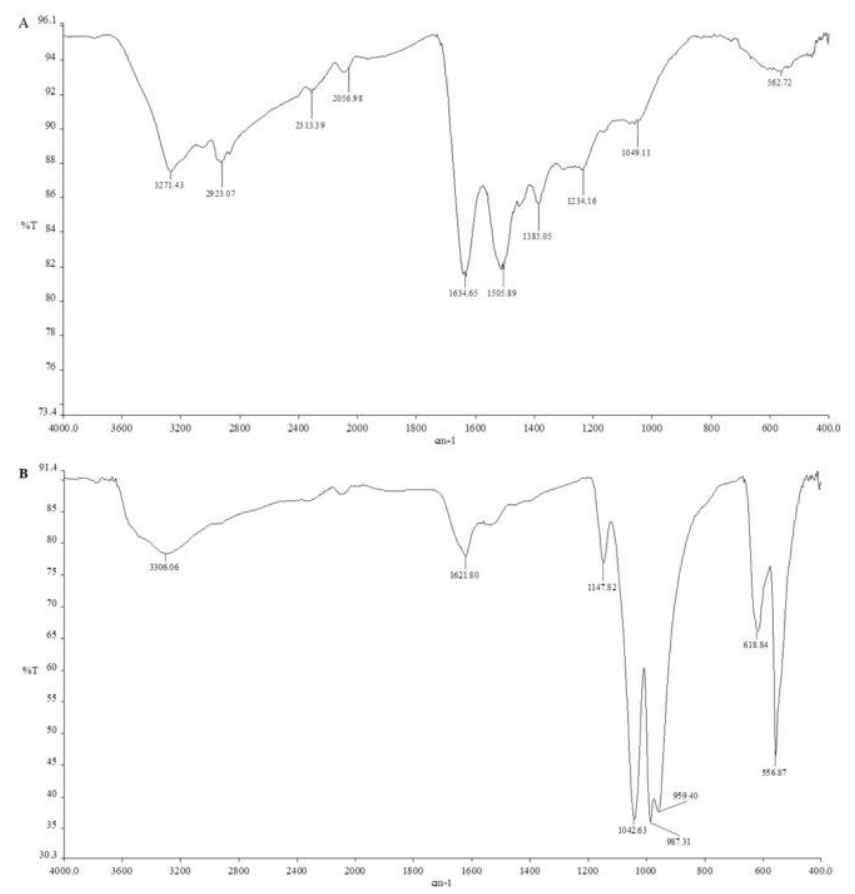

Figure 3. FTIR analysis of (A) free HRP and (B) MhNFs.

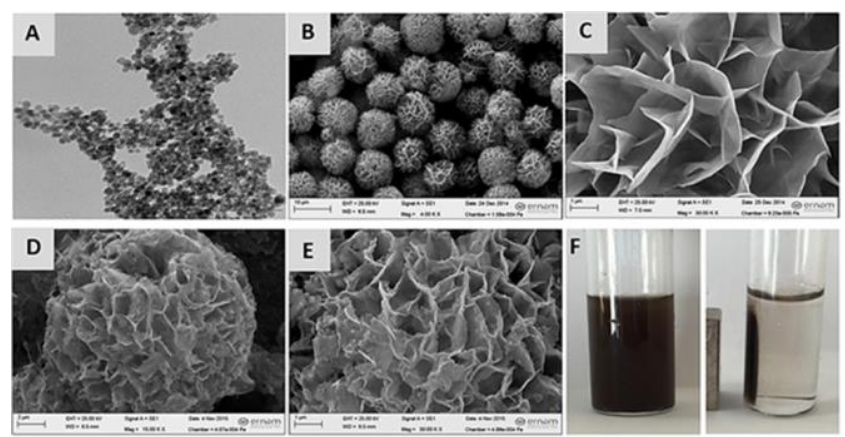

Figure 4. SEM images (A) $\mathrm{Fe}_{3} \mathrm{O}_{4} \mathrm{NPs}$, (B) hNFs, (C) magnified hNFs, (D) MhNF (E) magnified and (F) photographs of MhNF solution with (right) and without (left) a magnet (E).

Interestingly, collected MhNFs still stayed on the vial wall for a long time when a magnet was removed. It also indicates that MhNFs was highly magnetized in the presence of an external magnetic field. The magnetic properties of MhNFs were utilized for their separation from reaction media without any centrifugation. It is also noteworthy to mention that MhNFs allowed us for recycling use for phenol removal.

\subsection{Activity measurements}

The protein encapsulation yields of synthesized MhNFs were calculated as $\sim 98 \%$ for all synthesis conditions. The activity measurements of magnetic hybrid nanoflower (MhNF) were performed by spectroscopic methods using guaiacol and $\mathrm{H}_{2} \mathrm{O}_{2}$ as substrates. In all activity and stability measurement experiments, the MhNFs (prepared from $0.02 \mathrm{mg} \mathrm{mL}^{-1} \mathrm{HRP}$ and $0.8 \mathrm{mM}$ $\mathrm{Cu}^{2+}$ ) and an identical concentration of HRP based 
nonmagnetic hybrid nanoflower (hNF) and free HRP were used. A standard activity measurement protocol $\left(\mathrm{pH} 6.8,0.1 \mathrm{M} \mathrm{KH}_{2} \mathrm{PO}_{4}, 25{ }^{\circ} \mathrm{C}\right)$ was applied in order to determine the activities of MhNFs, hNFs and free HRP. HRP catalyzes the oxidation of guaiacol to produce the orange colored quinone type structure, 3,3-dimethoxy4,4-diphenoquinone [23,27]. This colored product allowed to monitor the activities of free HRP, synthesized hNFs and MhNFs with the spectrophotometrically with the increase in the absorbance of the product at $470 \mathrm{~nm}$. In this study, one enzyme activity unit of horseradish peroxidase (HRP) (EU) was defined as the amount of horseradish peroxidase (HRP) required to catalyze 1 $\mu \mathrm{mol}$ of substrate per minute under the specified reaction conditions. The activities of free HRP, hNF and MhNF were calculated as 5847.6, 16738.2, and 18830.5 $\mathrm{EU} / \mathrm{mg}$, respectively. The activity differences in the nanoflowers are due to the expansion of the pore width and surface area of the structure. In addition, combining the structure with the magnetic particle caused to increase in enzymatic activity.

\subsection{Removal of phenol using magnetic hybrid nanoflower (MhNFs)}

HRP catalyzes the oxidation of several organic and inorganic substrates including phenols in the presence of $\mathrm{H}_{2} \mathrm{O}_{2}$. The effect of $\mathrm{pH}$ and time on the removal of phenol are given in Fig. 5A and 5B, respectively.

The optimum $\mathrm{pH}$ of the MhNFs for phenol removal was determined as pH 7 (Fig. 5A). For this reason, different time studies and the reusability experiments were then performed at $\mathrm{pH}$ 7. As can be seen from Fig. 5B, almost $85 \%$ removal of phenol was done in one hour and $100 \%$ removal of phenol was performed in 2 hours for free HRP. On the other hand, almost 97\% removal of phenol for MhNFs was performed in 20 minutes and 100\% removal of phenol was performed in 30 minutes. It can be seen from the Fig. 5B, the phenol removal performance of MhNF is higher than free HRP. In addition to the higher phenol removal performance of MhNFs compared to free HRP, reusability of the MhNFs makes them very attractive.

The reusability of free enzymes are still unsolved issue for their efficient use. Although hNFs was re-used for collecting them from reaction media via centrifugation, some undesired cases occurred during the centrifugation step. For instance, 1) the morphology of hNFs was deformed after a few cycles, which causes a severe reduction in catalytic activity of hNFs, 2) when the mixture of hNFs and substrate was centrifuged at high speed, some portion of substrate insert into the substrate, then it may give false positive response and 3) the insertion of substrate into the boundaries of hNFs may restrict both capacity and activity of hNFs. In here, we developed a novel design to make hNFs magnetic and called MhNFs.

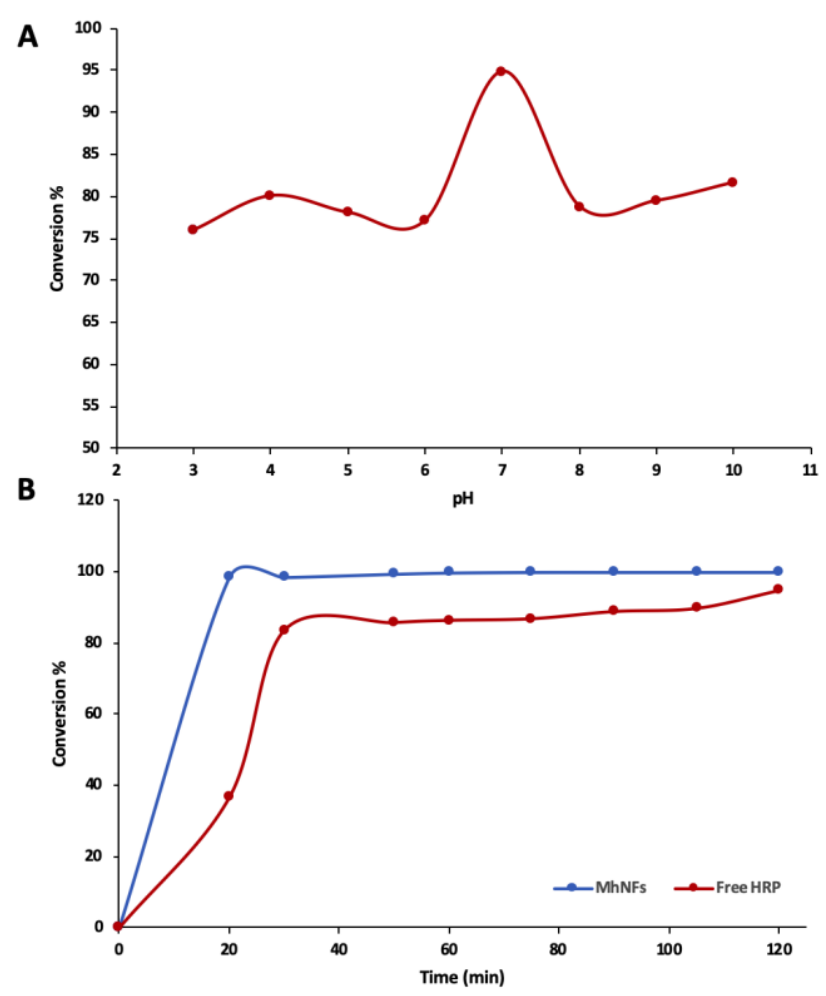

Figure 5. A) The effect of $\mathrm{pH}$ on the removal of phenol removal $\mathrm{B}$ ) the effect of time on the removal of phenol

(Red line: Free HRP, Blue line: MhNFs)

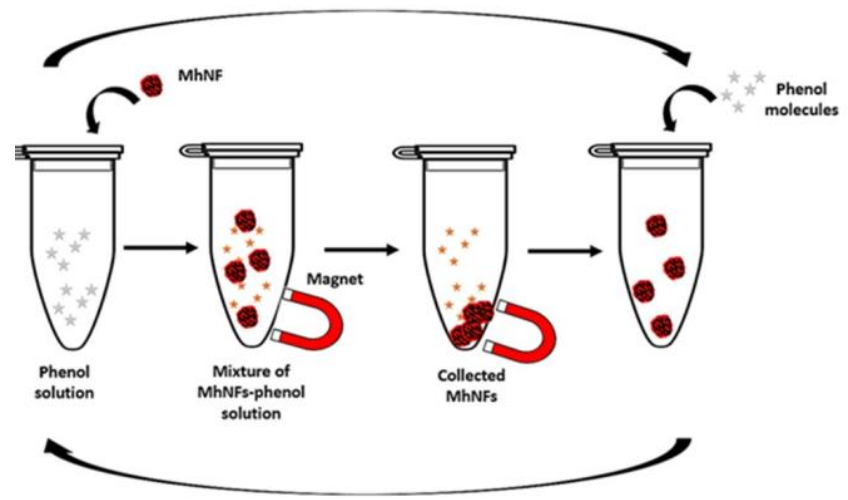

Figure 6. The schematic representation of magnetic hybrid nanoflower's reusability

Fig. 6 showed the schematic representation of magnetic hybrid nanoflower's reusability. Fig 7 showed that the same MhNFs was repeatedly used for phenol removal in success. Even after seven cycles, MhNFs maintained more than $\sim 75 \%$ of their initial activity. In typical recycling test the phenol solution was simply mixed with suspension of MhNFs and followed by reaction at RT for some time. The MhNFs were rapidly separated from the suspension by a magnet and the supernatant was removed by a pipet for its absorption measurement. The new phenol solution was added to the MhNFs for next catalytic experiment. Thus, magnetic property of MhNFs make them to use repeatedly. 


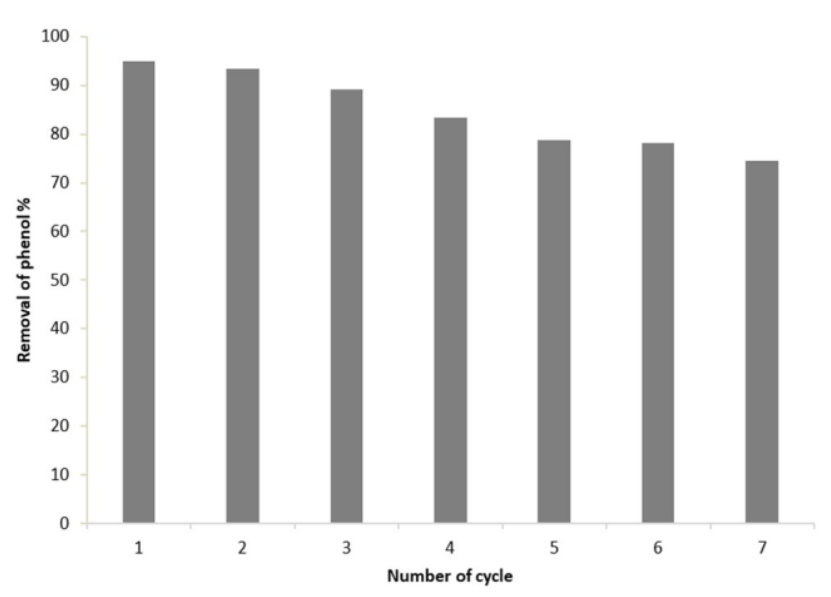

Figure 7 The reusability of magnetic hybrid nanoflower (MhNF)

\section{Conclusion}

In summary, we were provided the magnetic $\mathrm{Fe}_{3} \mathrm{O}_{4}$ particles and $\mathrm{HRP}-\mathrm{Cu}^{2+}$ hybrid nanoflower are synthesized separately, and then combined to obtain magnetic properties. Our magnetic property basedhybrid materials indicated high enhanced activity, stability, reusability and applicability for use in removal of phenol compared with free HRP enzyme. The optimum $\mathrm{pH}$ for magnetic hybrid nanoflower (MhNF) was found 7.0 for phenol removal reactions. When MhNFs was magnetized in the presence of an external magnetic field, it was utilized for their separation from reaction media without any centrifugation for phenol degradation. So that, MhNF was easily removed from reaction medium for reusability. The proposed method has an advantage for rapid response, excellent intervention, and saving time. The magnetic hybrid nanoflower (MhNF) have great potential as visual biosensor in green chemistry. Besides that, our technologic application's to proteininorganic nanoflowers can offer a new platform in many areas such as biomedical, biotechnology, nanobiotechnology and chemistry.

\section{Acknowledgment}

This work was supported by TÜBİTAK (The Scientific and Technical Research Council of Turkey) project number 115Z092. We thank the technology research and application center of Erciyes University for SEM, EDX, $\mathrm{XRD}$ and FTIR analysis. There are no conflicts to declare.

\section{References}

[1] Erdem, H., Kalın, R., Özdemir, N. Özdemir, H., "Purification and biochemical characterization of peroxidase isolated from white cabbage (Brassica Oleracea var. capitata f. alba)", Int. J. Food Pro., 18, 2099-2109, 2015.

[2] Kalın, R., Atasever, A., Özdemir, H., "The single-step purification of peroxidase by 4- aminobenzohydrazide from turkish black radish (Raphanus sativus L.) and turnip (Brassica rapa L.) roots". Food Chem., 150, 335-340, 2014.

[3] Somturk, B., Kalın, R., Özdemir, N., "Purification of peroxidase from red cabbage (Brassica oleracea var. capitata f. rubra) by affinity chromatography." Appl. Biochem. Biotechnol.,173, 1815-1828, 2014.

[4] Alemzadeh, I., Nejati, S., "Phenols removal by immobilized horseradish peroxidase". J. Hazard. Mater., 166 (2-3), 1082-1086, 2009.

[5] Homaei, A. A., Sariri, R., Vianello, F., Stevanato, R., "Enzyme immobilization: an update". J Chem Biol, 6, 185-205, 2013.

[6] Wang, S., Fang, H., Wen, Y., Cai, M., Liu, W., He, S., Xu, X., "Applications of HRP-immobilized catalytic beads to the removal of 2,4-dichlorophenol from wastewater". RSC Advances, 5, 57286, 2015.

[7] Vahidi, A.K., Yang, Y., Ngo, T.P.N., Li, Z., "Simple and Efficient Immobilization of Extracellular His-Tagged Enzyme Directly from Cell Culture Supernatant As Active and Recyclable Nanobiocatalyst: HighPerformance Production of Biodiesel from Waste Grease". ACS Catal.; 5, 3157-3161, 2015.

[8] Kim, J., Grate, J.W., Wang, P., "Nanostructures for enzyme stabilization". Chem. Eng. Sci.; 61, 10171026, 2006.

[9] Garcia-Galan, C., Berenguer-Murcia, A., FernandezLafuente, R., Rodrigues, R.C., "Potential of different enzyme immobilization strategies to improve enzyme performance". Adv. Synth. Catal.; 353, 2885 2904, 2011.

[10] Jiang, D., Long, S., Huang, J., Xiao, H., Zhou, J., "Immobilization of pycnoporus sanguineus laccase on magnetic chitosan microspheres". Biochem. Eng. J.; 25, 15-23, 2005.

[11] Lathouder, K., Bakker, J., Kreutzer, M.T., Kapteijn, F., Moulijn, J.A., Wallin, A., "Structure dreactors for enzyme immobilization: advantages of tuning the wall morphology", Chem. Eng. Sci.; 59, 5027 - 5033, 2004.

[12] Asgher, M., Shahid, M., Kamal, S., Iqbal, H.M.N, "Recent trends and valorization of immobilization strategies and ligninolytic enzymes by industrial biotechnology". J. Mol. Catal. B: Enzym., 101, 56- 66, 2014.

[13] Fernandes, K.F., Lima, C.S., Pinho, H., Collins, C.H., "Immobilization of horseradish peroxidase onto polyaniline polymers". Process Biochem.,38, 13791384, 2003.

[14] Altinkaynak C., "Hemoglobin-metal ${ }^{2+}$ phosphate nanoflowers with enhanced peroxidase-like activities and their performance in the visual detection of hydrogen peroxide". New Journal of Chemistry., (45), 1573, 2021.

[15] Ge, J., Lei, J., Zare, R.N., "Protein-inorganic hybrid nanoflowers". Nat. Nanotechnol., July, 428-432, 2012.

[16] Altinkaynak, C., Tavlasoglu, S., Kalin, R., Sadeghian, N., Özdemir, H., Ocsoy, I., Özdemir, N., "A 
Hierarchical assembly of flower-like hybrid Turkish black radish peroxidase- $\mathrm{Cu}^{2+}$ nanobiocatalyst and its effective use in dye decolorization". Chemosphere, 182, 122-128, 2017

[17] Altinkaynak, C., Kocazorbaz, E., Özdemir, N., Zihnioglu, F., E"gg white hybrid nanoflower (EWhNF) with biomimetic polyphenol oxidase reactivity: Synthesis, characterization and potential use in decolorization of synthetic dyes". Int. J. Biol. Macromol; 109, 205-211, 2018.

[18] Cheon, H.J., Adhikari, MD., Chung, M., Tran, TD., Kim, J., Kim, MI., “Magnetic Nanoparticles-Embedded Enzyme-Inorganic Hybrid Nanoflowers with Enhanced Peroxidase-Like Activity and Substrate Channeling for Glucose Biosensing". Adv. Healthcare Mater.; 1801507, 2019.

[19] Feng, N., Zhang, H., Li, Y., Liu, Y., Xu, L, Wang, Y., Fei, X., Tian, J., "A novel catalytic material for hydrolyzing cow's milk allergenic proteins: Papain-

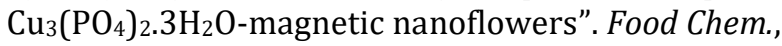
311, 125911, 2020.

[20] Guo, J., Wang, Y., Zhao, M., "A self-activated nanobiocatalytic cascade system based on an enzyme-inorganic hybrid nanoflowers for colorimetric and visual detection of glucose in human serum". Sensor Actuat B-Chem., 284, 45-54, 2019.

[21] Gulmez, C., Altinkaynak, C., Özdemir, N., Atakisi, O., "Proteinase $\mathrm{K}$ hybrid nanoflowers (P-hNFs) as a novel nanobiocatalytic detergent additive". Int. J. Biol. Macromol., 119, 803-810, 2018.

[22] Han, J., Luo, P., Wang, L., Li, C., Mao, Y., Wang, Y., "Construction of magnetic biocatalytic system with enhanced enzymatic performance by biomineralization and its application for bisphenol A removal". J.Hazard. Mater.; 380, 120901, 2019.

[23] Ke, C., Fan, Y., Chen, Y., Xu, L., Yan, Y., "A new lipase-inorganic hybrid nanoflower enhanced enzyme activity", RSC Adv., 6, 19413-1941, 2016.

[24] Lee, I., Cheon, H.J., Adhikari, M.D., Tran, T.D., Yeon, T-D., Kim, MI., Kim, I., "Glucose oxidase-copper hybrid nanoflowers embedded with magnetic nanoparticles as an effective antibacterial agent". Int J Biol Macromol., 155, 1520-1531, 2020.

[25] Wang, L.B., Wang, Y.C., He, R., Zhuang, A., Wang, X., Zeng, J., Hou, J.G., "A New nanobiocatalytic system based on allosteric effect with dramatically enhanced enzymatic performance". J. Am. Chem. Soc; 135, 1272-1275, 2013.

[26] Wang, K-Y., Bu, S-J., Ju, C-J., Li, C-T., Li, Z-T., Han, Y., Ma, C-Y, Wang, C-Y, Hao, Z., Liu, W-S., Wan, J-Y., "Hemin-incorporated nanoflowers as enzyme mimics for colorimetric detection of foodborne pathogenic bacteria. Bioorg". Med. Chem. lett. 28, 2324, 2018.

[27] Wu, X., Hou, M., Ge, J., "Metal-organic frameworks and inorganic nanoflowers: a type of emerging inorganic crystal nanocarrier for enzyme immobilization". Catal. Sci. Technol. 5, 5077-5085, 2015.

[28] Zhang, B., Li, P., Zhang, H., Li, X., Tian, L., Wang, H., Chen, X., Ali, N., Ali, Z., Zhang, Q., "Red-blood-celllike $\mathrm{BSA} / \mathrm{Zn}_{3}\left(\mathrm{PO}_{4}\right)_{2}$ hybrid particles: Preparation and application to adsorption of heavy metal ions". Appl. Surf. Sci. 366, 328-338, 2016.

[29] Zhang, B., Chen, J., Wang, J., Huyan, Y., Zhang, H., Zhang, Q., "Flowerlike $\mathrm{BSA} / \mathrm{Zn}\left(\mathrm{PO}_{4}\right)_{2} / \mathrm{Fe}_{3} \mathrm{O}_{4}$ Magnetic Hybrid Particles: Preparation and Application to Adsorption of Copper Ions". J.Chem. Eng Data,; 63, 3913-3922, 2018.

[30] Ahmaruzzaman, M., Gayatri, S.L., "Activated tea waste as a potential low-cost adsorbent for the removal of p-nitrophenol from wastewater". J. Chem. Eng. Data., 55, 4614-4623, 2010.

[31] Torres, E., Bustos-Jaimes, I., Le Borgne, S., "Potential use of oxidative enzymes for the detoxification of organic pollutants", Appl. Catal. B: Environ:; 46, 1-15, 2003.

[32] Wang, M., Qi, W., Su, R., He, Z., "Advances in carrier-bound and carrier-free immobilized nanobiocatalysts", Chem. Eng. Sci.; 135, 21-32, 2015.

[33] Durán, N., Esposito, E., "Potential applications of oxidative enzymes and phenoloxidase-like compounds in wastewater and soil treatment: a review", Appl. Catal. B: Environ.; 28, 83-99, 2009.

[34] Fernandes, K.F., Lima, C.S., Lopes, F.M., Collins, C.H., "Properties of horseradish peroxidase immobilized onto polyaniline". Process Biochem,; 39, 957-962, 2004.

[35] Karam, J., Nicell, J.A, "Potential applications of enzymes in waste treatment". J. Chem. Technol. Biotechnol.,; 69, 141-148, 1997.

[36] Lai, Y.C., Lin, S.C., "Application of immobilized horseradish peroxidase for the removal of $p$ chlorophenol from aqueous solution". Process Biochem.; 40, 1167-1174, 2005.

[37] Yamada, K., Akiba, Y., Shibuya, T., Kashiwada, A., Matsuda, K., Hirata, M., "Water purification through bioconversion of phenol compounds by tyrosinase and chemical adsorption by chitosan beads". Biotechnol. Prog., 21, 823-829, 2005.

[38] Zhao, Z., Zhang, J., Wang, M., Wang, Z., Wang, L., Ma, L., Huang, X., Li, X., "Structure advantage and peroxidase activity enhancement of deuteroheminpeptide-inorganic hybrid flowers", RSC $A d v$., 6, 104265-104272, 2016.

\section{ACKNOWLEDGEMENTS}

This work was supported by TÜBİTAK (The Scientific and Technical Research Council of Turkey) project number 115Z092. We thank the technology research and application center of Erciyes University for SEM, EDX, XRD and FTIR analysis. There are no conflicts to declare. 